Yazıcı, E., ve Kurudayıoğlu, M. (2017). 5. sınıf Türkçe ders kitaplarındaki dinleme metinlerinin öğrencilerin seviyesine uygunluğunun incelenmesi. Ana Dili Eğitimi Dergisi, 5(4), 967-984.

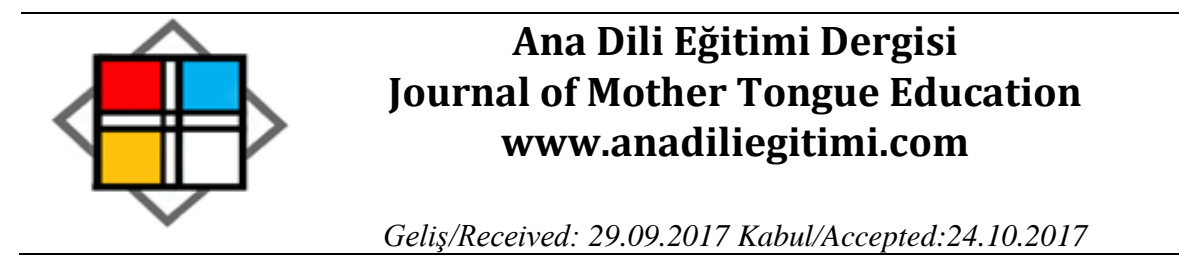

\title{
5. Sınıf Türkçe Ders Kitaplarındaki Dinleme Metinlerinin Öğrencilerin Seviyesine Uygunluğunun İncelenmesi*
}

\author{
Emre YAZICI ${ }^{* *}$ \\ Mehmet KURUDAYIOĞLU***
}

Öz

\begin{abstract}
Bu araştırma beşinci sınıf Türkçe ders kitaplarındaki bilgilendirici metin ve hikâye edici metinlerden oluşan iki kategorideki dinleme metinlerinin sınıf düzeyine uygunluğunun belirlenmesi amacıyla gerçekleşmiştir. Ulusoy ve Çetinkaya (2012), tarafından geçerli ve güvenilir olma durumu test edilmiş olan Cümle Doğrulama Tekniği ile gerçekleştirilen bu çalışma, Yozgat ilinin Yenifakıı ilçesinde bulunan Şehit Cuma Karadavut İmam Hatip Ortaokulu 5. sınıfı bitirmiş öğrencilerinden 11 kız öğrenci ve 7 erkek öğrenci; i̇stanbul ilinin Bağcılar ilçesinde olan Ziya Gökalp Ortaokulu altıncı sınıf öğrencilerinden 16 kız ve 15 erkek öğrenci; Gaziantep ilinin Oğuzeli ilçesinden Atatürk Ortaokulu altıncı sınıf öğrencilerinden 12 kız ve 23 erkek öğrenci olmak üzere 84 öğrenci üzerinde yapılmıştır. Araştırma öğrenci seviyeleri ile dinleme metinlerinin seviyelerinin karşlıklı incelenmesi amacıyla yapıldığından beşinci sınıf dinleme metinleri beşinci sınıfı yeni bitirmiş ve altıncı sınıfın başlarında olan öğrenciler üzerinden çalışma gerçekleştirilmiştir. Araştırma tarama modelinde gerçekleştirilmiştir. Araştırmadan elde edilen bulgulara göre hikâye edici metinlerde erkek ve kız öğrencilerin başarı oranı iyi düzeyde görülmektedir. Bilgilendirici metinlerde ise erkek ve kız öğrencilerin başarı oranı zayıf düzey olarak tespit edilmiştir. Bununla birlikte hikâye edici metinlerde öğrencilerin iyi düzeyde olduğu, bilgilendirici metinlerde ise hem erkek öğrenciler hem de kız öğrenciler açısından zor metinler olduğu görülmektedir.
\end{abstract}

Anahtar Sözcükler: cümle doğrulama tekniği, Türkçe ders kitabı, dinleme eğitimi, ölçme ve değerlendirme

\section{Examination of the Appropriateness of Listening Texts in the 5th Grade of Turkish Textbooks to Students' Level}

\begin{abstract}
This research was conducted to determine the appropriateness of the listening texts in the two categories of informative text and narrative texts in the fifth grade Turkish textbooks to the class level. This study conducted by Sentence Verification Technique of whose reliability and validity was tested by Ulusoy and Çetinkaya (2012) was made on 11 female and 7 male students from the 5th grade of Şehit Cuma Karadavut Imam Hatip Secondary School in Yenifakılı district of Yozgat province; 16 female and 15 male students from the 6th grade of Ziya Gökalp Middle School in Bağcılar district of Istanbul province; 12 female and 23 male students from the 12th grade of Ataturk secondary school in Oğuzeli district of Gaziantep province, totaling 84 students. Since the
\end{abstract}

\footnotetext{
*28-30 Eylül 2017 tarihleri arasında Okan Üniversitesi'nde düzenlenen 10. Uluslararası Türkçenin Eğitimi ve Öğretimi Kurultayı'nda sunulan sözlü bildirinin genişletilmiş şeklidir.

${ }^{* *}$ Arş. Gör., Yıldız Teknik Üniversitesi, Eğitim Fakültesi, Türkçe ve Sosyal Bilimler Eğitimi Bölümü, eyazici@yildiz.edu.tr

${ }^{* * *}$ Doç. Dr., Abant İzzet Baysal Üniversitesi, Eğitim Fakültesi, Türkçe ve Sosyal Bilimler Eğitimi Bölümü, mkurudayi@hotmail.com.
} 
research was carried out to examine the levels of listening texts and levels of students mutually, the study was carried out on the 6th grade students who just completed the 5 th grade and listening texts of the 5 th grades. The research was conducted on a scanning model. According to the findings received from the research, the success rate of male and female students was good in narrative texts. In informative texts, the success rate of boys and girls was found to be low. Additionally, it can be seen that in informative texts in which the students are at a good level in storytelling texts, there were difficult texts for male students and female students.

Keywords: sentence verification technique, Turkish coursebook, listening education, assessment and evaluation

\section{Giriş}

Dinlemenin ilk basamağı olan işitme, insanoğlunun henüz anne rahminde iken edinmeye başladığı bir beceridir. Bu yönüyle dinleme, dil edinimi sürecinin olmazsa olmaz bir parçasıdır. Bireyin diğer dil becerileri konuşma, okuma ve yazma, dinleme becerisinin üzerine inşa edilmektedir. Kısaca sesli iletileri anlama süreci olarak tanımlayabileceğimiz dinlemenin değişik boyutları ve işlevleri dikkate alınarak farklı tanımları yapılmıştır. Dilin dört becerisinden biri olan dinleme hakkında çok sayıda tarif yazılmıştır. Dinlemek kelimesi Türkçe Sözlük'te (TDK, 2011: 671b) “işitmek için kulak vermek” olarak tarif edilmektedir; ancak bu tanımda ifade edilen dinlemenin bir dil becerisi olarak beceri olma, anlama süreci olması vasfını ortaya koymada eksik kaldığı görülmektedir.

Dinlemenin diğer tariflerine bakıldığında "konuşan kişinin vermek istediği mesajı pürüzsüz olarak anlayabilme ve söz konusu uyarana karşı tepkide bulunabilme etkinliği” (Demirel, 1999: 33), seslerin ve varsa konuşma kodlarının farkında olunması ve bu kodlara dikkat edilmesiyle başlayan belli işitme işaretlerinin tanınması ve hatırlanmasıyla süren ve zihinde anlamlandırılmasıyla son bulan psikolojik bir süreç ya da görme ve işitme simgelerine tepki (Ergin ve Birol, 2000: 113-115) ifadelerini görmek mümkündür. Bu ifadelerden hareketle dinlemenin konuşucu ile muhatap arasında gerçekleşen iletişim sürecinin aktif bir anlama çabası olduğunu söylemek mümkündür.

Türkçenin kullanımı sürecinde dinleme ve işitme arasındaki farkı anlamak da dinlemenin sınırlarını çizmek bakımında faydalı olabilecektir. İşitme fizikî bir durumken dinleme işitmeyi de içinde barındıran

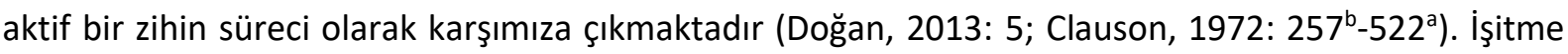
gayriihtiyari olabilirken dinlemede insanın aktif bir çabası gerekmektedir.

Dinlemenin bir beceri olarak geliştirilmesindeki temel amaç ise kişinin sözlü iletişim sürecini daha etkili ve verimli şekilde kullanabilmesinin sağlanmasıdır. Yerine getirilmesi güç sanılan, ustalık isteyen bir işi yapabilme durumu (Sulak, 2016: 56) olan beceri, kişilerin kolaylıkla ve kusursuz olarak yapmasını öğrendiği her şey olarak tarif edilmektedir (Öncül, 2000: I, 125ª). Bu yönüyle dinleme eğitimi de konuşma eğitimiyle beraber bireylerin zorlanmadan ustalıkla sözlü iletişim sürecine dâhil olmasını hedeflemektedir. 
5. Sınıf Türkçe Ders Kitaplarındaki Dinleme Metinlerinin Öğrencilerin Seviyesine Uygunluğunun İncelenmesi

Doğan (2008)'ın farklı araştırmacılardan aktardığına göre Rankin (1930)'in araştırmasında dinlemeye \%42, konuşmaya \%32, okumaya \%15 ve yazmaya \%11 zaman ayrıldığı; Bird (1953)'ün araştırmasında dinlemeye $\% 42$, konuşmaya $\% 25$, okumaya $\% 15$, yazmaya $\% 18$ oranında zaman ayrıldığı; Burley-Allen (1995)'in yaptığı araştırmada dinlemenin \%40, konuşmanın \%35, okumanın \%16 ve yazmanın \%9 oranında kullanıldığı ve son olarak da Robertson (2004)'un yaptığı araştırmada ise ilköğretim okulu öğrencilerinin zamanının \%57'sini dinleme ile geçirdiği ifade edilmiştir. Yapılan araştırmalardan hareketle insanların iletişim halinde olduğu zaman dilimlerinin büyük kısmında dinleme becerisini kullandığını söylemek mümkündür.

İşitmek sesin sadece fiziksel boyutunu oluştururken dinlemek, işitmekten farklı olarak duyulanın anlamlandırılmasını da kapsamaktadır. Dinleme sürecinin sonucu olarak kişinin bir girdiye ulaşması hedeflenmektedir. Öğrencilerin öğrenme sürecinde en çok karşılaştıkları dil becerisinin dinleme olduğu düşünülecek olursa bu girdilerin doğruluğu oldukça önemlidir. Girdilerin doğruluğu ise ancak ölçme ve değerlendirme ile mümkün olmaktadır.

Çalışma kapsamında incelenen dinleme metinleri 2015 Türkçe Dersi Öğretim Programına göre hazırlanan MEB 5. Sınıf Türkçe ders kitabından ${ }^{1}$ alınmıştır. 2017 yııında program güncellenmiştir. Her iki programda da dinleme eğitimine yönelik kazanımlara yer verilmekte ve öğrencilerin dinleme becerisini diğer dil becerileri ile beraber geliştirmeleri hedeflenmektedir. Bu bağlamda 2015 Türkçe Dersi Öğretim Programındaki 5. Sınıf dinleme kazanımları şunlardır:

1. Dinlediklerindeki/izlediklerindeki ana fikri/ana duyguyu belirler.

2. Dinlediklerini/izlediklerini ön bilgileriyle karşılaştırır.

3. Dinledikleri/izledikleriyle ilgili çıkarımlar yapar.

4. Dinlediklerini/izlediklerini özetler.

5. Dinledikleri/izledikleriyle ilgili görüşlerini mantıksal sıra içerisinde açıklar.

6. Dinlediklerinde gerçek ve kurgu olanı ayırt eder.

2017 Türkçe Dersi Öğretim Programı’nda ise dinleme becerisine yönelik 5. Sınıf seviyesi için 12 kazanımın belirlendiği görülmektedir:

1. Dinlediklerinde /izlediklerinde geçen olayların gelişimi ve sonucu hakkında tahminde bulunur.

\footnotetext{
${ }^{1}$ Araştırmada incelenen Türkçe ders kitabı 2015 Türkçe Dersi Öğretim Programına göre MEB tarafından hazırlanmış ve sadece 2016-2017 eğitim-öğretim yılında bütün Türkiye'de tek kitap olarak okutulan kitaptır.
} 
2. Dinlediklerinde/izlediklerinde geçen, bilmediği kelimelerin anlamını tahmin eder.

3. Dinlediklerinin/izlediklerinin konusunu belirler.

4. Dinlediklerinin/izlediklerinin ana fikrini/ana duygusunu tespit eder.

5. Dinlediklerini/izlediklerini özetler.

6. Dinledikleri/izlediklerine yönelik sorulara cevap verir.

7. Dinlediklerine/izlediklerine yönelik farklı başlıklar önerir.

8. Dinlediği/izlediği hikâye edici metinleri canlandırır.

9. Konuşmacının sözlü olmayan mesajlarını kavrar.

10. Dinlediklerinin/izlediklerinin içeriğini değerlendirir.

11. Dinledikleriyle/izledikleriyle ilgili görüşlerini bildirir.

12. Dinleme stratejilerini uygular.

Öğrencilerin istenen kazanımları elde edilip edilmediğinin tespit edilmesi dinlediğini anlamaya yönelik ölçme değerlendirme süreci işlemleriyle mümkündür. Bu sebeple dinleme becerilerinin ölçülmesi ve bu ölçme işlemlerinden elde edilen verilerin değerlendirilmesi için farklı yöntemler geliştirilmiştir. Dinlemeyi ölçme ve değerlendirme yöntemlerinden birisi de Cümle Doğrulama Tekniği olarak karşımıza çıkmaktadır (Akyol, Yıldıım, Ateş, Çetinkaya ve Rasinski, 2014; Ulusoy ve Çetinkaya, 2012). Cümle Doğrulama Tekniği ayrıca okuma ve dinleme metinlerinin öğrenci seviyesine uygun olup olmadığının sınanması maksadıyla da kullanılabilir. Bu çalışmada CDT ders kitabına alınan dinleme metinlerinin öğrenci seviyesine uygunluğunun belirlenmesinde kullanılmıştır. Çünkü eğitim ve öğretim materyallerinde bulunması gereken özelliklerin başında öğrenci seviyesine uygunluğu gelmektedir. Bu bağlamda CDT, öğrencilere sunulacak dinleme metinlerinin seviyeye uygunluğunun belirlenmesi sürecinde çok rahat kullanılabilir.

\section{Cümle Doğrulama Tekniği}

Ölçme ve değerlendirme süreci hedefe ulaşma yolunda ara noktalarda ve amaç noktalarda Türkçe dersini alan öğrencilerin gelişme durumlarını belirlemek için kullanılmaktadır. Keza hedefe ne ölçüde vardığımızı anlamak ve bu amaçla dinleme becerisi gibi alanlarda becerilerin ve davranışların ölçülmesi zarûrîyet ifade etmektedir (Kavcar, Oğuzkan ve Sever, 1995: 103). Bunu da ölçmenin yöntemlerinden biri Cümle Doğrulama Tekniği [CDT (Sentence Verification Technique)]'dir. Bu teknik 
5. Sınıf Türkçe Ders Kitaplarındaki Dinleme Metinlerinin Öğrencilerin Seviyesine Uygunluğunun İncelenmesi

Royer, Hastings ve Hook tarafından 1979 yılında geliştirilmiştir. ${ }^{2}$ CDT için seçilen metinler kendi içinde tutarlı, anlaşıır ve başka metinlerden bağımsız olmalıdır. CDT testi anlamanın yapısal bir işlem olduğu fikrinden etkilenmiştir. Bu görüşe göre okuyucu, bir metni okuyup anladığında metinde okuduğu her cümle hakkında içerisinde anlamı saklayan hafıza simgeleri oluşturmaktadır (Shaughnessy, 2005: 280).

CDT’nin hazırlanma aşaması: CDT testini hazırlayanlar kendi içinde anlamı olan 12 cümlelik metinler belirlerler. Belirlenen her cümle ile ilgili dört cümle çeşidi arasından birisine göre yeni cümle oluşturulur. Royer (2001: 33-34) bu cümle çeşitlerini:

\section{Orijinal (original)}

2. Başka kelimelerle ifade etme (paraphrase)

3. Anlamı Değiştirme (meaning change)

4. Çeldiriciler (dictractor) olarak dört aşamada açıklamaktadır.

Orijinal cümlede yazmada, metindeki cümle forma aynı şekilde, hiçbir değişiklik yapılmadan aktarılır.

Metinde: Herkesin imrenerek baktığı bahçesinin yerini yıllar önce çok az paraya almıştı.

Uygulamada: Herkesin imrenerek baktığı bahçesinin yerini yıllar önce çok az paraya almıştı.

Başka kelimelerle ifade etmede, orijinal metinde bulunan cümlenin sözcükler bazındaki ifadeleri anlamı bozmamaya önem gösterilerek değiştirilir.

Metinde: Görüldünüz mü ya bir taş sıyırıp geçerdi yanınızdan, ya da silahtan çıkan bir mermi.

Uygulamada: Görüldüğünüzde ya bir taş hemen yanınızdan geçerdi ya da silahtan fırlayan bir mermi.

Anlamı değistirilen cümlelerde, orijinal metinde bulunan sözcüklerden bir-iki tanesi değiştirilerek orijinal cümledeki anlamın değiştirilmesi sağlanır.

Metinde: Musa Emmi çevrenin en çalışkan insanıydı.

Uygulamada: Musa Emmi çevredeki en tembel insandı.

Çeldirici ifadelerde ise metinin temasının dışına çıkmamak şartıyla metinde yer almayan cümle yazılır.

\footnotetext{
2ilgili kaynak için bkz: Royer, J. M., Hastings, C. N., Hook C. (1979a). A sentence verification technique for measuring reading comprehension. Journal of Reading Behavior, 11, 355-263.
} 
Öğrenciler CDT için hazırlanan metni bir kez dinledikten-okuduktan sonra, evet veya hayır seçeneklerinden oluşan soruları cevaplamaya başlarlar. Öğrenciler, testte yer alan cümleler ile metinde yer alan cümleleri aynı görüyorsa evet, farklı olduğunu düşünüyorsa hayır seçeneğini işaretlerler. Farklı sözcüklerle ifade etme ve orijinal cümlelerde evet, anlamı değiştirme ve çeldiricilerde hayır seçeneği doğru cevap olarak kabul edilmektedir (Royer, 2001: 34).

Royer'e göre CDT Test tekniğinde testin iki seçenekli olduğu ve \% 50 şans faktörünün de olduğu düşünülerek, \% 71- 79 arasındaki başarı orta, \% 80'in üzerindeki doğru cevaplar ise iyi düzeydeki anlamayı göstermektedir (Royer, 2001: 39-40).

Araştırmanın temel amacı, MEB tarafından hazırlanan 5. Sınıf Türkçe Ders Kitabındaki dinleme metinlerinin CDT ile öğrenci seviyesine uygunluğunun belirlenmesidir. Bu temel amaç çerçevesinde araştırmanın alt amaçları şunlardır:

1. Hikâye edici metinlerin öğrenci seviyesine uygunluğunu cinsiyete göre ve genel olarak tespit etmek.

2. Bilgilendirici metinlerin öğrenci seviyesine uygunluğunu cinsiyete göre ve genel olarak tespit etmek.

\section{Araştırmanın Modeli}

Araştırmada tarama modeli kullanılmıştır. Tarama modelinin seçilmesinin sebebi Karasar’a göre (2016) hadiseleri olduğu gibi alma ve kaydetmedir; ancak kaydedilen durumları yorumlamak da zaruridir. Tarama modeli iki amaçla gerçekleştirilmektedir. Birincisi mevcut şartları tanımak ve problemi çözme, açıklama vb. ikincisi ise çalışmalar için gerekli bilgilerin toplanarak tasnif edilmesidir. Bu araştırmada da dinleme metinlerinin öğrenci seviyesine uygunluk durumu tespit edilecektir.

Tarama modeli geçmişte veya halen var olan bir durumu var olduğu şekliyle tespit etmeyi amaçlayan bir araştırma modelidir. Araştırmaya konu olan hadise, vaka, kişi ya da nesne kendi şartları içinde ve olduğu gibi tarif edilmeye çalışılmaktadır. Onları herhangi bir şekilde değiştirme veya etkileme çabası gösterilmemektedir. Bilinmek istenen şey vardır ve oradadır. Mühim olan onu uygun bir şekilde gösterip belgeleyebilmektir (Karasar, 2016: 109).

\section{Çalışma Grubu}

Araştırma öğrenci seviyeleri ile dinleme metinlerinin seviyelerinin karşılıklı incelenmesi amacıyla gerçekleştirildiğinden dolayı beşinci sınıf dinleme metinleri beşinci sınıfı yeni bitirmiş ve altıncı sınıfın başlarında olan öğrenciler üzerinden gerçekleştirilmiştir. 
5. Sınıf Türkçe Ders Kitaplarındaki Dinleme Metinlerinin Öğrencilerin Seviyesine Uygunluğunun İncelenmesi

Tablo 1. Çalışma Grubu ve Okullar

\begin{tabular}{llll}
\hline Okul Bilgisi & Kız & Erkek & Toplam \\
\hline Atatürk Ortaokulu & 12 & 23 & 35 \\
\hline $\begin{array}{l}\text { Şehit Cuma Karadavut } \\
\text { İmam Hatip Ortaokulu }\end{array}$ & 11 & 7 & 18 \\
\hline Ziya Gökalp Ortaokulu & 16 & & 31 \\
\hline Toplam & 39 & 15 & 84 \\
\hline
\end{tabular}

Uygulamaya katılan okullar ve öğrenci sayılarına ilişkin veriler Tablo-1'de verilmiştir. Çalışma Gaziantep ilinin Oğuzeli ilçesinden Atatürk Ortaokulu (birinci okul) altıncı sınıf öğrencilerinden 12 kız ve 23 erkek öğrenci; Yozgat ilinin Yenifakılı ilçesinde bulunan Şehit Cuma Karadavut İmam Hatip Ortaokulu (ikinci okul) altıncı sınıf öğrencilerinden 11 kız öğrenci ve 7 erkek öğrenci; İstanbul ilinin Bağcılar ilçesinde olan Ziya Gökalp Ortaokulu (üçüncü okul) altıncı sınıf öğrencilerinden 16 kız ve 15 erkek öğrenci olmak üzere toplam 84 öğrenci üzerinde yapılmıştır.

\section{Verilerin Toplanması ve Analizi}

Metin türleri bilgilendirici ve hikâye edici olmak üzere iki başlıktan oluşmaktadır (Hall, Sabey, McClellan, 2005: 212). Bu sebeple araştırmada öğrencilere bilgilendirici ve hikâye edici metin türlerinden formlar oluşturulmuş ve cümle doğrulama tekniğinin kriterleri doğrultusunda çalışma gurubunu oluşturan öğrencilere uygulanmıştır. Bilgilendirici metinleri incelemeye yönelik olarak 5. sınıf Türkçe ders kitabındaki Vergibilir isimli metin kullanılmıştır. Hikâye edici metin olarak da 5. Sınıf Türkçe ders kitabındaki Gecekarası Adında Bir Karga isimli dinleme metni incelenmiştir.

Uygulamaya hazırlanma aşamasında hikâye edici ve bilgilendirici metinlerden birer metin seçilmiştir. Seçilen metinlerden 1. Orijinal (original) 2. Başka kelimelerle ifade etme (paraphrase) 3. Anlamı Değiştirme (meaning change) 4. Çeldiriciler (dictractor) başlıklarına uygun olarak formlar (Ek-1, Ek-2) hazırlanmıştır. Uzman görüşüne sunularak son şekli verilen formlar öğrencilerin evet ya da hayır seçenekleriyle cevaplaması istenerek öğrencilere dağıtılmıştır. Dağıtılan formlar öğrencilerin dinleme metnini bir kez dinlemesi sonrasında öğrenciler tarafından doldurulmuştur.

Öğrencilerden formda karşılaştıkları cümle ile dinledikleri metindeki cümleler aynı anlama geliyorsa evet, farklı anlama geliyorsa hayır seçeneğini işaretlemeleri istenmiş ve formlar bu şekilde doldurtulmuştur. Doldurulan formlar ise başka sözcüklerle ifade etme ve orijinal cümlelerde evet, anlamı değiştirme ve çeldiricilerde ise hayır cevabı doğru kabul edilerek araştırmacılar tarafından değerlendirilmiştir.

Elde edilen veriler şans faktörü de gözetilerek Royer (2001) tarafından hazırlanmış olan başarı kriterlerine göre \%70 ve aşağısındaki cevap oranları başarısız, \%71-79 arasındaki başarı oranları orta ve 
\%80 ve üzerindeki doğru cevap oranları ise iyi düzey anlamayı gösterir olarak kabul edilmiştir. Yapılan analizler neticesinde elde edilen veriler tablo ve grafikler yoluyla sunulmuş ve yorumlanmıştır.

\section{Bulgular}

Bu bölümde $C D T$ uygulaması sonucunda metin türlerine ve cinsiyetlere göre elde edilen bulgular ayrı ayrı işlenecektir.

Hikâye Edici Metinlerin Öğrencilerin Seviyesine Uygunluğuna iliş̧kin Bulgular

Hikâye edici dinleme metinlerine yönelik yapılan CDT uygulaması ile elde edilen veriler uygulama okullarına ve cinsiyetlerine göre ayrı ayrı incelenmiş ve sayısal olarak hesaplanarak şekillerle sunulmuştur. Uygulama yapılan okullardan Atatürk Ortaokulundaki durum cinsiyetlerine göre Şekil1 'de yer almaktadır.

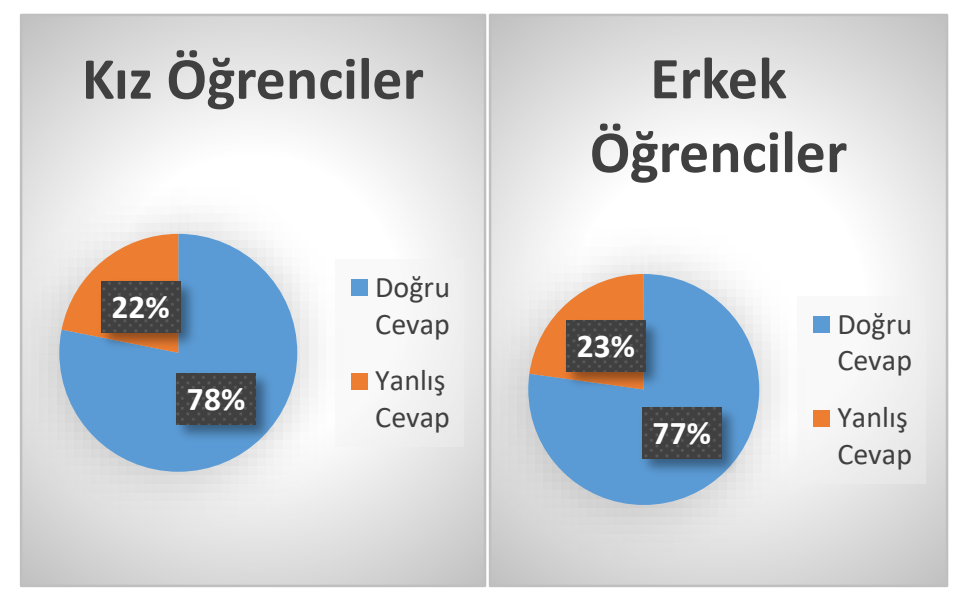

Şekil 1.Hikâye Edici Metinlerde Atatürk Ortaokulundaki Durum

Araştırmada birinci okulunun kız öğrencilerinden toplam 192 cevap alınmıştır. Alınan cevapların ise 150 tanesi doğru cevap olarak işaretlendiği tespit edilmiştir. Araştırmada alınan toplam cevaplar ve doğru cevaplar kendi arasında değerlendirildiğinde ise başarı oranı \%78,12 olarak hesaplanmıştır.

Aynı okulun erkek öğrencilerinden ise toplam 368 cevap alınmıştır. Alınan cevapların ise 284 tanesi doğru cevap olarak tespit edilmiştir. Alınan toplam cevap ve doğru cevaplar kendi aralarında incelendiğinde başarı oranı \%77, 17 olarak hesaplanmıştır. Bu verilerden hareketle Atatürk Ortaokulundan uygulamaya katılan kız ve erkek öğrencilerin anlama düzeylerinin orta seviyede olduğu ve test edilen dinleme metninin de öğrenci seviyesine orta düzeyde uygun olduğu söylenebilir. 


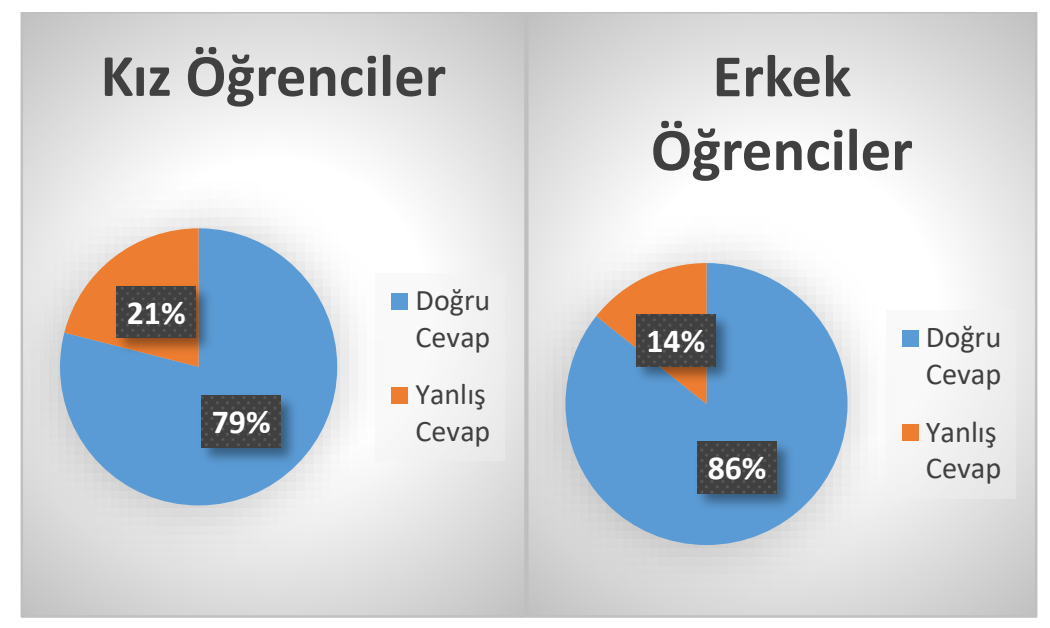

Şekil 2. Hikâye Edici Metinlerde Şehit Cuma Karadavut Imam Hatip Ortaokulundaki Durum

Araştırmada ikinci okulunun kız öğrencilerinden toplam 176 cevap alınmıştır. Alınan cevapların ise 139 tanesinin doğru cevap olduğu tespit edilmiştir. Tüm cevapların içerisinde doğru cevaplar oranlandığında ise başarı oranı \%78,97'dir. Buna bağlı olarak anlama düzeyi de orta seviye olarak tespit edilmiştir.

Okulun erkek öğrencilerinden ise toplam 112 cevap alınmıştır. Alınan bu cevapların 96 tanesinin doğru cevap olduğu tespit edilmiştir. Alınan toplam cevap ile doğru cevapların oranı ise $\% 85,71$ 'dir. Buradan hareketle öğrencilerin anlama düzeylerinin iyi seviyede olduğu görülmektedir. Bu hesaplamalar neticesinde test edilen dinleme metninin kız öğrencilerin seviyesine orta düzeyde erkek öğrencilerin seviyesine ise iyi düzeyde uygun olduğu söylenebilir.

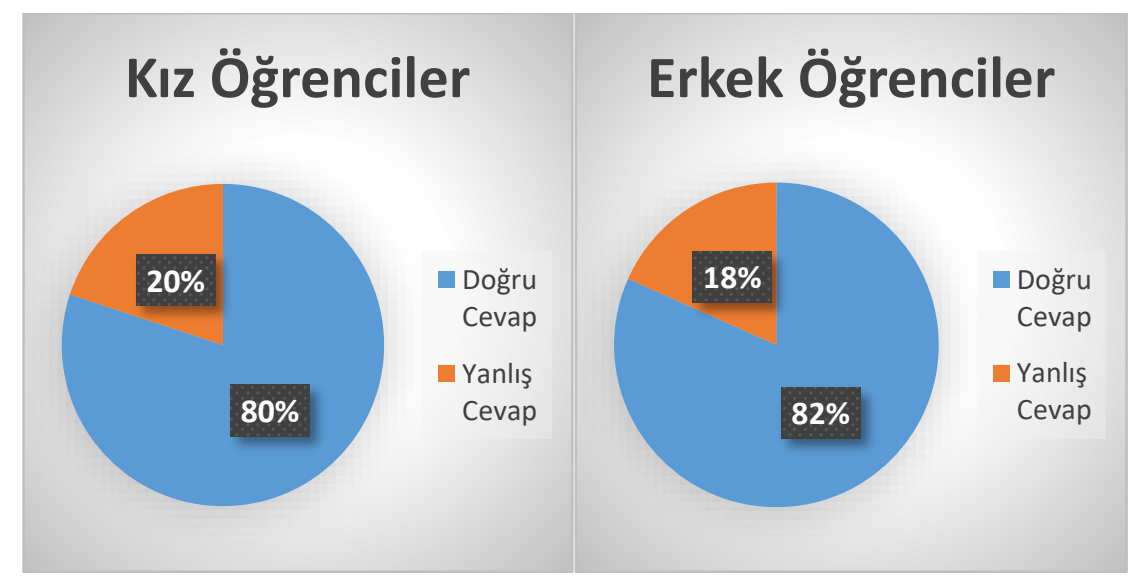

Şekil 3. Hikâye Edici Metinlerde Ziya Gökalp Ortaokulunun Durumu

Araştırmanın üçüncü ve son okulunun kız öğrencilerinden toplam 256 cevap alınmıştır. Alınan bu toplam cevapların 205 tanesinin doğru cevap olduğu tespit edilmiştir. Alınan doğru cevapların toplam cevaba oranı ise $\% 80,07$ olarak hesaplanmıştır. 
Okulun erkek öğrencilerinden ise toplam 240 cevap alınmıştır. Alınan toplam cevapların içinde 196 tanesinin doğru cevap olduğu tespit edilmiştir. Doğru cevapların toplam cevaplara oranı da \%81,66 olarak hesaplanmıştır. Bu sonuçlar, Şehit Cuma Karadavut İmam Hatip Ortaokulu'ndan uygulamaya katılan kız ve erkek öğrencilerin anlama düzeylerinin iyi olduğunu göstermektedir. Bu bulgudan hareketle test edilen dinleme metninin hem kız hem de erkek öğrencilerin seviyesine uygunluğu açısından iyi düzeyde olduğu söylenebilir.

Hikâye edici metinlere yönelik yapılan CDT testinin erkek ve kı öğrencilerinin anlama düzeylerine ilişkin veriler şekil-4'te verilmiştir.

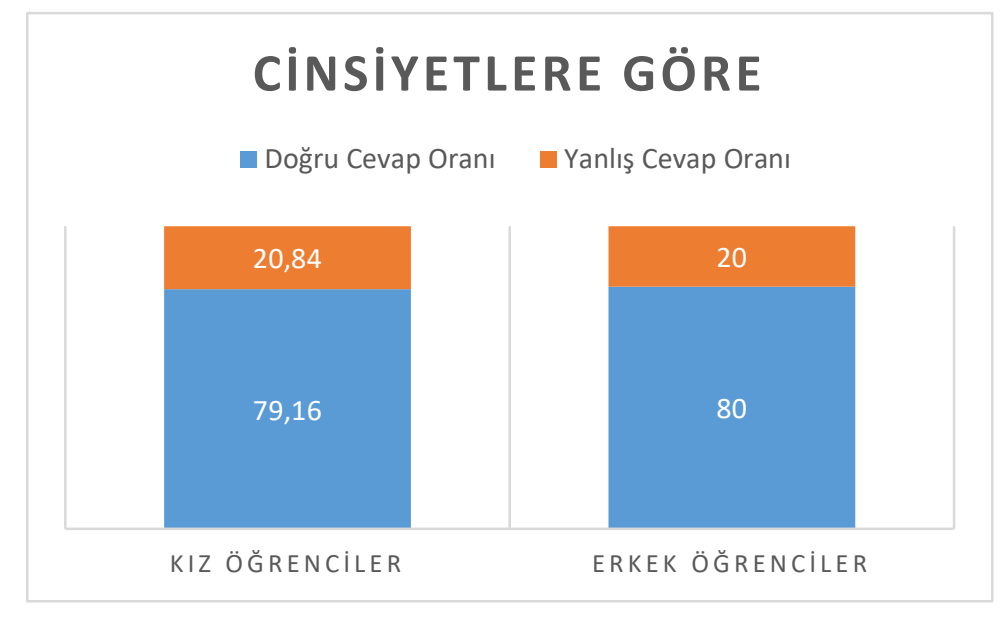

Şekil 4. Hikâye Edici Dinleme Metinlerinin Cinsiyetlere Göre Durumu

Uygulama yapılan üç okuldan alınan cevaplar bir bütün olarak değerlendirildiğinde kız öğrencilerden toplam 494 doğru cevap ve 130 yanlış cevap alınmıştır. Doğru cevapların toplam cevaba oranı ise $\% 79,16$ (orta düzey üst sınırı) olarak hesaplanmıştır.

Hikâye edici metinler açısından bakıldığında üç okulda erkek öğrencilerden toplam 576 doğru cevap ve 144 yanlış cevap alınmıştır. Doğru cevapların toplam cevaplara oranı ise \%80,00 (iyi düzey) başarı oranı olarak hesaplanmıştır. Görüldüğü gibi her iki grubun ortalamaları birbirine çok yakın olmakla birlikte kız öğrencilerin anlama düzeyleri orta düzeyin üst sınırında erkek öğrencilerin anlama düzeyleri ise iyi seviyenin alt sınırında çıkmıştır.

Hikâye edici dinleme metinlerine yönelik olarak yapılan CDT sonuçlarına göre öğrencilerin tamamına ilişkin veriler şekil-5'te verilmiştir. 


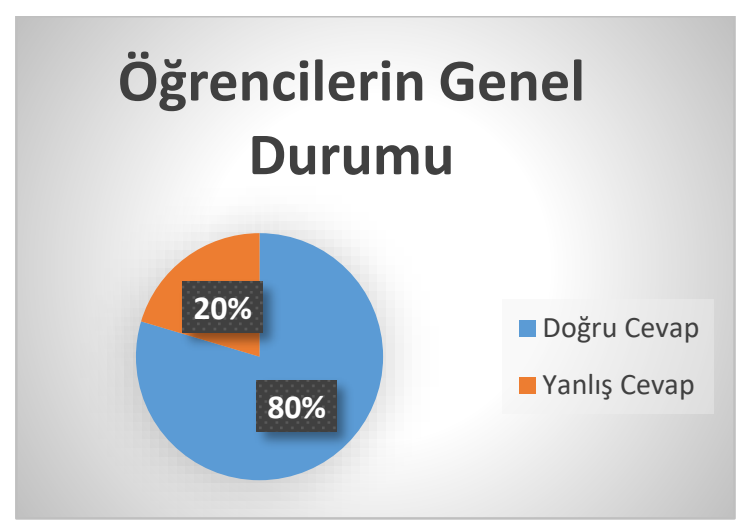

Şekil-5. Öğrencilerin Genelinin Hikâye Edici Metinleri Anlama Düzeyi

Hikâye edici metinlerde erkek ve kız öğrenciler olarak bakılmaksızın bütün öğrenciler birlikte değerlendirildiğinde toplamda 1344 cevap alınmıştır. Alınan cevapların 1070'inin doğru ve 274 'ünün de yanlış olduğu tespit edilmiştir. Doğru cevaplar toplam cevaplara oranlandığında ise başarı oranı toplamda \%79,61 (iyi düzey) olarak tespit edilmiştir.

Bu oranlardan hareketle hikâye edici dinleme metinlerinin uygulamaya katılan öğrencilerin seviyesine iyi seviyede uygun olduğu söylenebilir.

\section{Bilgilendirici Metinlerin Öğrencilerin Seviyesine Uygunluğuna ilişskin Bulgular}

Bilgilendirici metinlere yönelik yapılan CDT uygulaması ile elde edilen veriler, uygulama okullarına ve cinsiyetlere göre ayrı ayrı incelenmiş ve sayısal olarak hesaplanarak şekillerle sunulmuştur. Uygulama yapılan okullardan Atatürk Ortaokulundaki durum cinsiyetlere göre şekil-6'da sunulmaktadır.

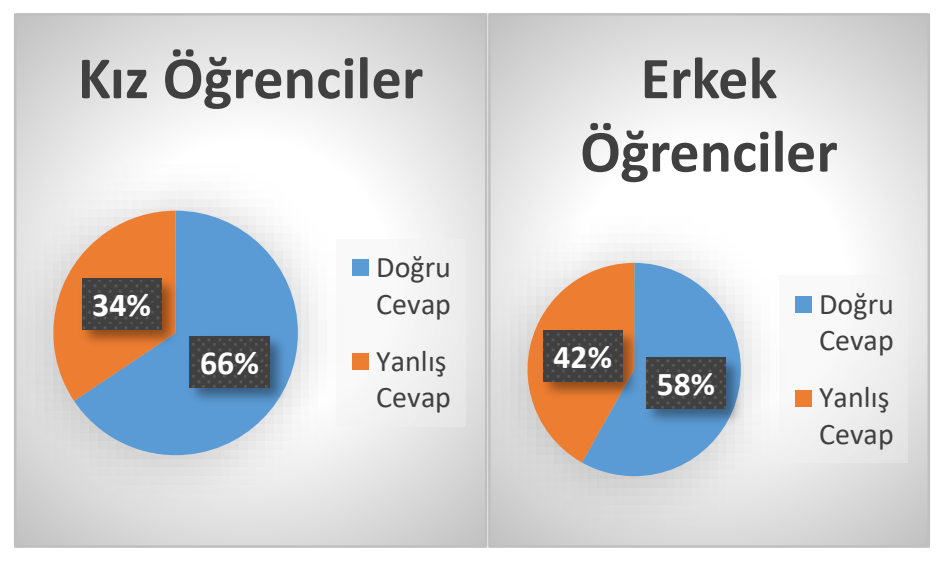

Şekil 6. Bilgilendirici Metinlerde Atatürk Ortaokulundaki Durum

Araştırmanın birinci okulundan bilgilendirici metinlere yönelik kız öğrencilerden toplam 192 cevap alınmıştır. Alınan cevapların da 126 tanesinin doğru olduğu tespit edilmiştir. Alınan doğru cevapların toplam cevaplara oranı da \%65,62 olarak hesaplanmış ve başarı oranı tespit edilmiştir. 
Okuldaki erkeklerin ise bilgilendirici metinlere yönelik toplam 368 cevap verdiği tespit edilmiştir. Alınan cevaplardan ise 214 tanesinin doğru cevap olduğu bulunmuştur. Alınan doğru cevapların da toplam cevaba oranı $\% 58,15$ olarak hesaplanmıştır.

Bu verilerden hareketle Atatürk Ortaokulundaki uygulamaya katılan kız ve erkek öğrencilerin anlama düzeylerinin zayıf olduğu ve test edilen dinleme metninin öğrenci seviyesine göre zor düzeyde olduğu söylenebilir.

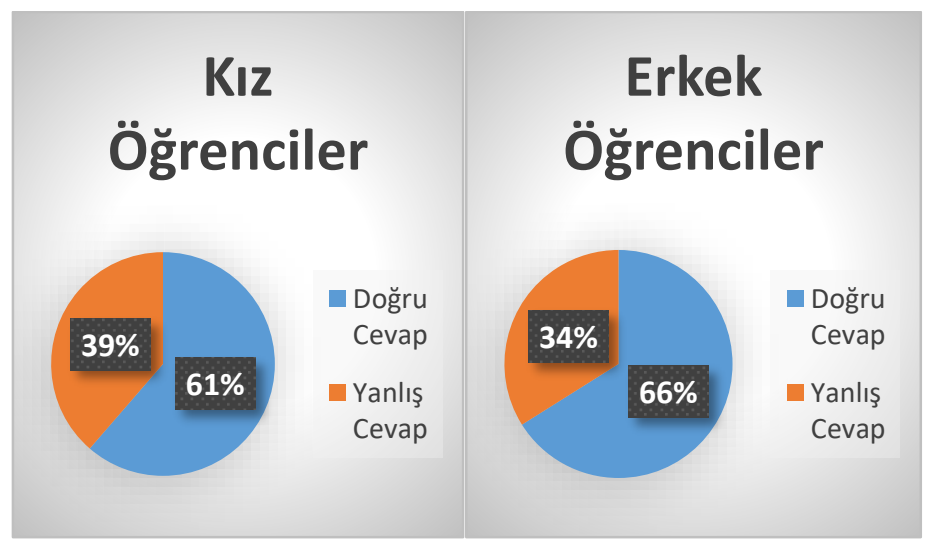

Şekil 7. Bilgilendirici Metinlerde Şehit Cuma Karadavut Imam Hatip Ortaokulundaki Durum

Araştırmanın ikinci okulunda kız öğrencilerden toplam 176 cevap alınmıştır. Alınan toplam cevabın ise 108 tanesinin doğru cevap olduğu tespit edilmiştir. Doğru cevaplar toplam cevaplara oranlandığında başarı oranı \%61,36 olarak hesaplanmıştır.

Araştırmanın ikinci okulunda ise erkek öğrencilerden toplam 112 cevap alınmıştır. Alınan cevaplardan da 74 tanesinin doğru cevap olduğu tespit edilmiştir. Doğru cevapların toplam cevaba oranı da \%66,07 olarak hesaplanmış ve başarı oranı tespit edilmiştir. Yani öğrencilerin anlama düzeylerinin zayıf olduğu görülmektedir. Bu hesaplamalar neticesinde test edilen dinleme metninin kız ve erkek öğrencilere göre zor düzeyde olduğu söylenebilir.

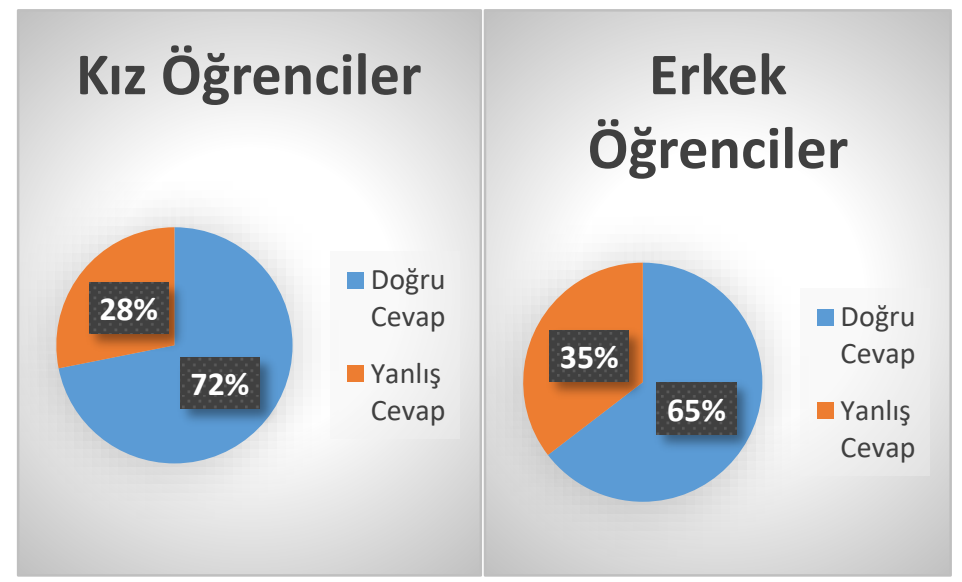

Şekil 8. Bilgilendirici Metinlerde Ziya Gökalp Ortaokulundaki Durum 
5. Sınıf Türkçe Ders Kitaplarındaki Dinleme Metinlerinin Öğrencilerin Seviyesine Uygunluğunun İncelenmesi

Araştırmanın üçüncü ve son okulunda ise kız öğrencilerden toplam 256 cevap alınmıştır. Alınan bu toplam cevabın ise 184 tanesinin doğru cevap olduğu tespit edilmiştir. Doğru olduğu tespit edilen cevapların toplam cevaba oranı hesaplandığında başarı oranı \%71,87 olarak bulunmuştur.

Araştırmanın üçüncü okulundan bu kez de erkek öğrencilerden toplamda 240 cevap alınmıştır. Alınan bu toplam cevabın ise 155 tanesinin doğru cevap olduğu tespit edilmiştir. Doğru olduğu tespit edilen cevapların toplam cevaba oranı hesaplandığında da başarı oranı \%64,58 olarak karşımıza çıkmaktadır.

Bu verilerden hareketle Ziya Gökalp Ortaokulundan uygulamaya katılan kız öğrencilerin anlama seviyelerinin orta düzey alt sınırında olduğu ve erkek öğrencilerin de anlama düzeylerinin zayıf olduğu görülmektedir. Metin, kız öğrencilere göre orta seviyede olsa da erkek öğrencilere göre zayıf seviyededir. Bununla birlikte kız öğrencilerin orta seviyenin alt sınırında olmasından hareketle metnin öğrencilerin seviyelerine göre zor olduğu söylenebilir.

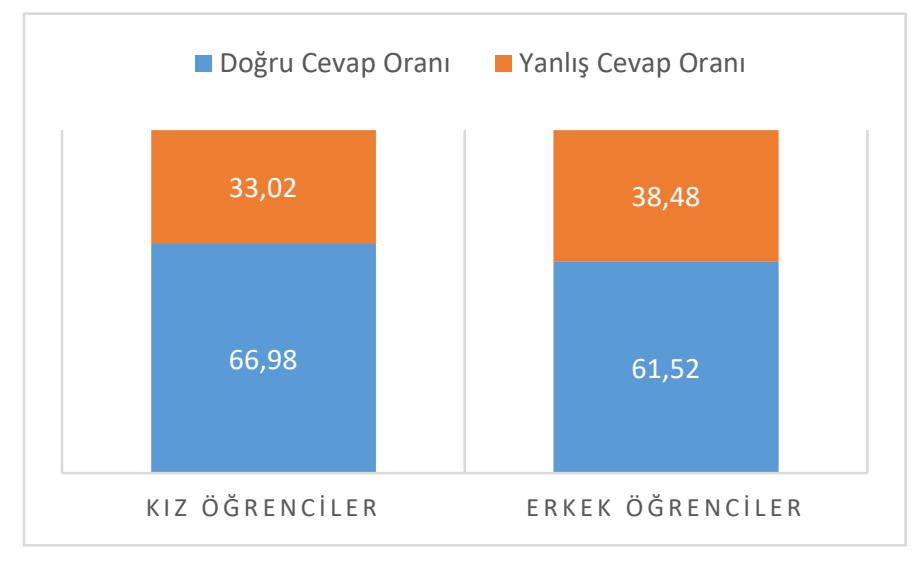

Şekil 9. Bilgilendirici Dinleme Metinlerinin Cinsiyetlere Göre Durumu

Şekil-9'da görüldüğü gibi uygulama okullarının tamamında bilgilendirici metinlere verilen cevaplara genel olarak bakıldığında erkek öğrencilerden toplam 720 cevap alınmıştır. Alınan bu cevapların 443'ünün doğru olduğu tespit edilmiştir. Doğru cevapların toplam cevaplara oranına bakıldığında ise erkek öğrencilerin bilgilendirici metinlerdeki başarı oranı $\% 61,52$ olarak düşük düzeyde olduğu görülmektedir. Kız öğrencilerde bilgilendirici metinlerde toplam 624 cevap alınmıştır. Alınan bu cevapların $418^{\prime}$ inin doğru olduğu tespit edilmiştir. Doğru cevapların toplam cevaplara oranına bakıldığında da kız öğrencilerin bilgilendirici metinlerde başarı oranı \%66,98 olarak yine düşük düzeyde olduğu tespit edilmiştir.

Görüldüğü gibi kız öğrencilerin anlama düzeylerinin erkek öğrencilere göre daha iyi olmasına rağmen her iki grubun da anlama seviyeleri zayıf düzey olarak çıkmıştır. 
Bilgilendirici türdeki dinleme metinlerine yönelik olarak yapılan CDT sonuçlarına göre öğrencilerin tamamına ilişkin veriler Şekil-10'da verilmiştir.

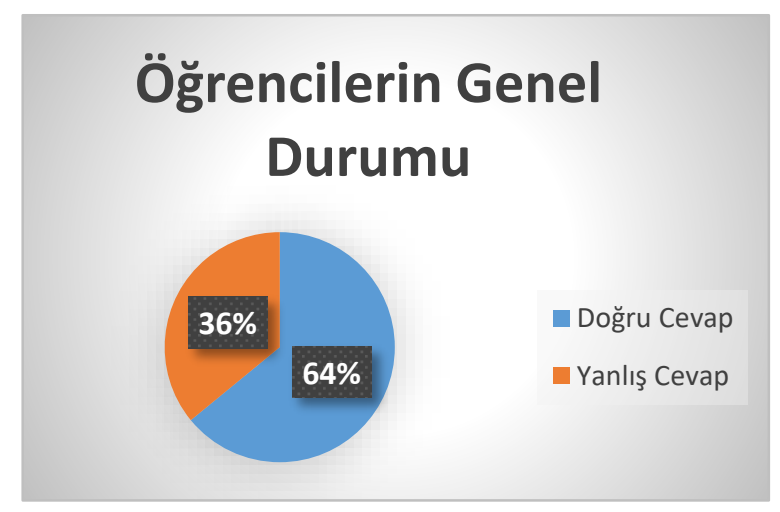

Şekil 10. Öğrencilerin Genelinin Bilgilendirici Metinleri Anlama Düzeyi

Bilgilendirici metinlere yönelik uygulamaya katılan öğrencilerin cinsiyet farklılıklarına bakılmaksızın öğrenciler bir bütün olarak değerlendirildiğinde toplamda 1344 cevap alınmıştır. Alınan cevapların da 861 tanesinin doğru cevap ve 483 tanesinin yanlış cevap olduğu tespit edilmiştir. Tespit edilen doğru cevapların toplam cevaplara oranı da \%64,06 düşük düzey olarak hesaplanmış ve bütün öğrencilerin bilgilendirici metinlerdeki başarı durumu zayıf seviye olarak tespit edilmiştir.

Bu oranlardan hareketle 5 sınıf Türkçe ders kitabında yer alan ve bu araştırma kapsamında incelenen bilgilendirici türdeki dinleme metninin uygulamaya katılan öğrencilerin anlama düzeylerine göre zor olduğu dolayısıyla da öğrenci seviyesine uygun olmadığı söylenebilir.

\section{Sonuç}

Öğrencilerin metinler üzerinden dil bilgisi ve metinler üzerinden dil becerilerini kazandıklarını düşünecek olursak metinler dil eğitimi açısından öğrencilerin zihni, sosyal ve zihni bağımsızlık becerilerini geliştirmek için birer araçtır (Güneş, 2013: 623); fakat bu metinler öğrencilerin seviyelerinin üstünde olursa öğrencilerde metinlere karşı isteksizlik yaşanmasına ve olumsuz tutum geliştirilmesine neden olabilecektir. Bütün bunlar göz önünde bulundurularak öğrencilerin önüne servis edilen metinlerin öğrencilerin seviyesine ait olması gerektiği tartışılmaz bir gerçektir. Bu yüzden ders kitaplarına seçilen metinlerin seviyeleri ön uygulamalar yapılarak değerlendirilmeli ve öğrenci seviyesine uygunluğu kanıtlanmış metinlere ders kitaplarında yer verilmelidir. Araştırmada kullanılan ölçek de ders kitapları için seçilen metinlerin seçilme aşamasında kullanılabilecek bir ölçek olarak tavsiye edilmektedir.

Araştırmada elde edilen bulgulara göre hikâye edici metinlerde erkek öğrencilerin başarı oranı \%80 ve kız öğrencilerin başarı oranı da \%79,16 olarak görülmektedir. Bilgilendirici metinlerde ise erkek 


\section{Sınıf Türkçe Ders Kitaplarındaki Dinleme Metinlerinin Öğrencilerin Seviyesine Uygunluğunun İncelenmesi}

öğrencilerin başarı oranı \%61,52 ve kız öğrencilerin başarı oranı da \%66,98 olarak tespit edilmiştir. Cümle doğrulama tekniğinde \%70 altındaki başarı oranları zayıf, 70-79 arası orta düzey ve 80 üzeri iyi düzey olduğu (Royer, 2001: 39-40) göz önünde bulundurulacak olursa hikâye edici metinlerde hem erkek öğrenciler hem de kız öğrenciler açısından metin seviyeleri iyi durumda bulunmaktadır. Bilgilendirici metinler ise hem erkek öğrenciler hem de kız öğrenciler açısından zor metinler olarak görülmektedir. Sonuç olarak beşinci sınıf ders kitaplarında bulunan dinleme metinleri iki ayrı başlık altında incelendiğinde hikâye edici metinler öğrencilerin seviyesi açısından iyi düzeyde bulunmaktadır. Bilgilendirici metinler ise öğrencilerin ve özellikle de erkek öğrencilerin seviyelerine göre zor anlaşılır seviyede bulunmaktadır.

Beşinci sınıf metinlerinin altıncı sınıf başındaki öğrencilere uygulandığı da göz önünde bulundurulacak olursa metinler daha kolay olarak hazırlanabilir. Hikâye edici metinler iyi düzey seviyesinin sınırları içerisinde iken bilgilendirici metinlerin düşük düzey (başarısız) olması münasebetiyle öğrencilere seviyelerine daha uygun bilgilendirici metinler sunulabilir.

Öğretmenler de gerek dersler gerekse ders harici çalışmalar için öğrencilere dinleme metinleri belirlerken metin seviyesinin sınıf seviyesine uygunluğunu değerlendirilmeleri açısından CDT tekniğini uygulayabilirler. Böylelikle öğrencilere sunulan etkinlik dinleme metinlerinin de öğrencilerin seviyesine ait metinlerden oluşması sağlanabilecektir.

Kitap hazırlanma aşamasında ise Türkçe öğretim programındaki kazanımlardan hareket edilerek ve cümle doğrulama tekniği kullanılarak hem öğrencilerin ulaşılması istenen kazanımlara ulaşılması hedeflenebilir hem de öğrencilerin bu seviyelere ulaşıp ulaşamadığı denetlenebilir.

\section{Kaynaklar}

Akyol, H. Yıldırım, K. Ateş, S. Çetinkaya, Ç. Rasinski, T. V. (2014). Okumayı değerlendirme öğretmenler için kolay ve pratik bir yol. Ankara: Pegem Akademi.

Clauson, G. (1972). An etymological dictionary of pre-thirteen century Turkish. Oxford: Oxford University Press.

Demirel, Ö. (1999). Illköğretim okullarında Türkçe öğretimi. İstanbul: MEB Basımevi.

Doğan, Y. (2008). Illköğretim yedinci sınıf öğrencilerinin dinleme becerisini geliştirmede etkinlik temelli çalışmaların etkililiği. Türk Eğitim Bilimleri Dergisi, 6 (2), 261-286.

Doğan, Y. (2013). Dinleme eğitimi. Ankara: Pegem Akademi.

Ergin, A. Birol C. (2000). Eğitimde iletişim. Ankara: An Yayıncılık.

Güneş, F. (2013). Türkçede metin öğretimi yerine metinle öğrenme. Adıyaman Üniversitesi Sosyal Bilimler Enstitüsü Dergisi Türkşenin Eğitimi Öğretimi Özel Sayısı, 6, 11, 603-637.

Hall, K. M., Sabey, B. L., Mcglellan, M. (2005). Expository text comprehension: Helping primary-grade teachers Use Expository Texts to Full Adventage. Reading Psycohology: 26, 211-234.

MEB (2015). Türkçe dersi (1-8. sınıflar) öğretim programı. Ankara: Millî Eğitim Bakanlığı 
MEB (2017) Türkçe dersi öğretim programı, Ankara: Milli Eğitim Bakanlığı,

MEB EBA (2017), Vergibilir 2,http://www.eba.gov.tr/video/izle/1954f162dc41c274e4e5cb3c671ac40c4ad57c76 b8007, 30 Eylül 2017 Cumartesi.

Karasar, N. (2016). Bilimsel irade algı çerçevesi ile bilimsel araştırma yöntemi: Kavramlar ilkeler teknikler. Ankara: Nobel Akademik Yayıncılık.

Kavcar, C., Oğuzkan, F. ve Sever, S. (1995). Türkçe ve sınıf öğretmenleri için Türkçe öğretimi. Ankara: Engin Yayınevi.

Öncül, R. (2000). Eğitim ve eğitim bilimleri sözlüğü (Terimlerin Almanca, Fransızca, İngilizce ve Eski Terim Karşılıkları ile). İstanbul: MEB Yayınları.

Royer, J. M. (2001). Developing reading and listening comprehension tests based on the sentence verification technique (SVT). Journal of Adolescent \& Adult Literacy, 45 (1), 30-41.

Royer, J. M., Hastings, C. N., Hook C. (1979a). A sentence verification technique for measuring reading comprehension. Journal of Reading Behavior, 11 (4), 355-263.

Shaughnessy, M. F. (2005). An interview with James M. Royer about reading and comprehension. Educational Psychology Review, 17 (3), 273-283.

Sulak, S. (2016). Anlamdaş kelimelerde anlam ve kullanış farklılıkları. Ankara: Gece Kitaplığı.

TDK. (2011). Türkçe sözlük. Ankara: Türk Dil Kurumu Yayınları.

Ulusoy, M., Çetinkaya, Ç. (2012). Cümle doğrulama tekniğinin okuma ve dinlemenin ölçülmesinde kullanılması. Hacettepe Üniversitesi Eğitim Fakültesi Dergisi, 43, 460-471. 


\section{Sınıf Türkçe Ders Kitaplarındaki Dinleme Metinlerinin Öğrencilerin Seviyesine Uygunluğunun İncelenmesi}

Ek-1: Hikâye Edici Metin Soru ve Cevap Formu

\begin{tabular}{|c|c|c|c|}
\hline & SORU & DOĞRU & YANLIŞ \\
\hline 1. & Kendisine 'Gecekarası' dendiğinde üzüntü duymuştu. & $x$ & \\
\hline 2. & Bu adla özdeşleşmek için siyahlaşmayı düşündü. & & $\mathrm{x}$ \\
\hline 3. & Gidip ırmaklara, göllere, denizlere attı kendini. & $x$ & \\
\hline 4. & Karga bu çirkin sesini duymaktan utanıyordu. & & $x$ \\
\hline 5. & Fındığı, cevizi, bademi kırmak da ayrı bir sıkıcıydı. & & $x$ \\
\hline 6. & illk heyecan dalından koparılırken başladı. & $\mathrm{x}$ & \\
\hline $\begin{array}{l}7 . \\
\text { firl }\end{array}$ & $\begin{array}{l}\text { Görüldüğünüzde ya bir taş hemen yanınızdan geçerdi ya da silahtan } \\
\text { bir mermi. }\end{array}$ & $x$ & \\
\hline
\end{tabular}

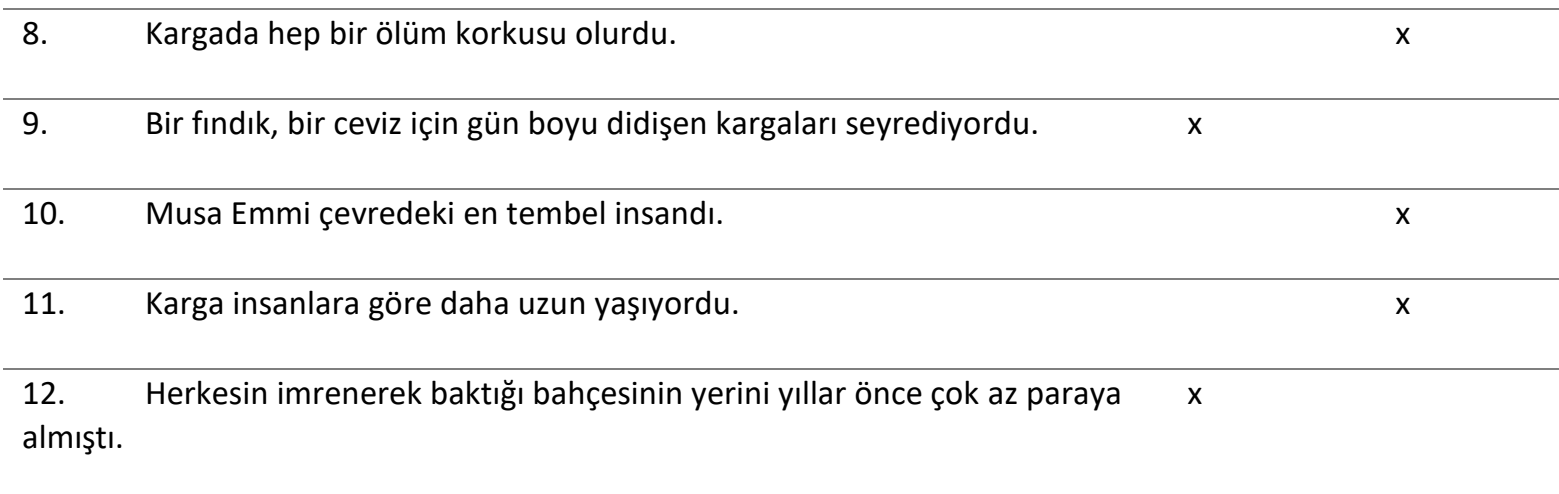

13. Kargaların fındığı, fıstı̆̆ı, cevizi yeme isteğiyle Musa Emminin $\quad x$ yedirmeme isteği eşitti.

14. Bu çarpışma azalmış, zamanla bitmişti.

$\mathrm{X}$

15. Musa Emmi haklıydı, çünkü o bahçeyi o yapmıştı.

$\mathrm{X}$

16. Kargalar haklıydı çünkü onlar dünyanın en güzel hayvanıydı.

$\mathrm{X}$ 


\begin{tabular}{|c|c|c|}
\hline SORU & DOĞRU & YANLIŞ \\
\hline $\begin{array}{l}\text { 1. Görüyoruz ki insanların hayatında para tarihin bütün bölümünde } \\
\text { önemli bir araç olmuş. }\end{array}$ & $\mathrm{x}$ & \\
\hline Binlerce yıl insanlar mağaralarda yaşam sürdürmüşler. & $\mathrm{x}$ & \\
\hline $\begin{array}{l}\text { 3. Illk insanlar ekip biçmeyi, üretim yapmayı bildiklerinden avcılık ve } \\
\text { toplayıcılık yapmamışlar. }\end{array}$ & & $\mathrm{x}$ \\
\hline $\begin{array}{l}\text { 4. İlk insanın hayatını kapsayan en büyük duygu nasıl yaşayacağı } \\
\text { korkusuydu. }\end{array}$ & & $\mathrm{x}$ \\
\hline $\begin{array}{l}5 . \quad \text { Insanlar toprağı işlemeyi, hayvanları evcilleştirmeyi başaramadığı için } \\
\text { yerleşik hayata geçmişler. }\end{array}$ & & $\mathrm{x}$ \\
\hline Tarihin ilerlemesiyle beraber insanların hayatı da değişmiş. & $\mathrm{x}$ & \\
\hline $\begin{array}{l}\text { 7. Tekerleğin icadıyla tarım faaliyetlerinin yanı sıra ticaret yaşamı } \\
\text { gelişmiş. }\end{array}$ & $\mathrm{x}$ & \\
\hline Tekerleğin icadıyla insanlar arasındaki mesafeler kısalmış. & & $\mathrm{x}$ \\
\hline Uygarlıkların ilerlemesiyle beraber yazının icadı gerçekleşmiş. & & $\mathrm{x}$ \\
\hline Yerleşik hayatla beraber kentler de kurulmaya başlamış. & $\mathrm{x}$ & \\
\hline Ticaret insanların-ülkelerin arasındaki iletişimi artırmış. & & $\mathrm{x}$ \\
\hline $\begin{array}{l}\text { 12. Ticaret yaşamının hızla ilerlemesi şehirleri ve ülkeleri birbirine bağlayan } \\
\text { yolların yapılması ihtiyacını doğurmuş. }\end{array}$ & $\mathrm{x}$ & \\
\hline $\begin{array}{l}\text { 13. Kar yağdığı zaman yollardaki karlar temizlenmediğinde okula ulaşmak } \\
\text { ne kadar zorlaşıyor. }\end{array}$ & $\mathrm{x}$ & \\
\hline $\begin{array}{l}\text { 14. Bilim insanları gelecekte yaşamı zorlaştırmaması için akıllı şehirlerin } \\
\text { olmayacağını söylüyorlar. }\end{array}$ & & $\mathrm{x}$ \\
\hline $\begin{array}{l}\text { 15. Bilim insanları havadan giden arabaların olacağını, evin içinde de } \\
\text { dışında da her şeyin otomatik olacağını ve tüm hizmetlerin robotlar tarafından } \\
\text { sağlanacağını söylüyorlar. }\end{array}$ & & $\mathrm{x}$ \\
\hline Bilim ve teknolojide hayallerin sınırı yok. & $\mathrm{x}$ & \\
\hline
\end{tabular}

